\title{
The College Library as Seen by a College President
}

Dr. McAfee, president of Wellesley College, read this paper at the general session of the A.C.R.L. on June $2 \mathrm{I}$, in Boston.

$\mathrm{I}^{\mathrm{s}}$ ANY other faculty member used the Wellesley College Library as little as does the president, his days on the faculty would be numbered in small numbers. It is common gossip that college presidents are apt to be illiterate, on the principle, I suppose, that they make so many speeches that they have no time to read. It would be truer to say that they have little time to use libraries because their desks are piled so high with publications which are sent to them to be reviewed that they have no time to pick their own reading matter.

Yet I submit that there is no officer in the college who should have more understanding of the library than the president. Each of them directs his office as a service agency to an institution which uses presidency and library as a means to the end of education. If either presidency or library becomes an end in itself, it fails to fulfill its essential function.

You and I have a good deal in common, and are subject to certain common temptations. America's educational tradition makes us both more or less "symbolic" and it is hard to preserve a sense of humor when one is invested with symbolic attributes. Presidents have colossal houses and impressive offices. They wear lurid gowns in academic processions, have special parking privileges on campuses, lend their signature to salary checks for monthly sums larger than the signer could accumulate in a lifetime.

The librarian commands a building which is usually the most monumental one on the campus. He approves expenditures of large items, always an appreciable proportion of the total college budget. He lays down laws, with or without tact, about the use of his library-quiet here, no smoking there, sign here, register there.

We're potent, we are-with property of the institution and in the interests of what? Certainly not ourselves if we would be true to our own purposes, but in the interests of the education which librarians and presidents facilitate.

It is easy to forget how really unimportant we are in our own right. A president has less reason for existence apart from the institution than the library does, but not much less. You know the danger signals for me and my presidential colleagues. While I was a teacher, I asked my college president for some advice about my office, and he said, "Don't bother me with that. That's what I hired you for." "I hired you" - a bad symptom when the college president begins to think of himself as the boss, his colleagues as his employees.

But having seen the threatened beam in my eye, I hasten to the potential mote 
in yours to remind you that there have been librarians who took satisfaction in having every book on the shelf all the time rather than in circulation where the book might be injured as a price for student use of it. There have been librarians who demanded silence at the expense of free inquiry, and I suspect an occasional one who has let convenience to the librarians be more decisive than service to colleagues in determining policy.

But presidents and librarians are, by and large, a conscientious lot. We are more apt to yield to a radically different type of temptation. In our full acceptance of the principle that we represent service agencies, we run the risk of letting ourselves perform so many services that we handicap ourselves in rendering real service.

\section{Custodian of Tools}

The librarian is the custodian of the most important tools at the disposal of the scholar. He must keep in touch with the latest models and see that they are on hand when needed, and he must keep the tried and true old ones in good, workable condition. He must encourage students, faculty and undergraduate, to handle their tools as effectively as possible. $\mathrm{He}$ is apt to do this best by being himself a workman who enjoys working with books, but he needs more than a fondness for books. He needs the art of spreading his enthusiasm to other workers.

If that be his task he needs to be the paragon which I have no doubt all of you are. He runs a risk unless he is a paragon.

When he has accepted his responsibility he is tempted to fulfill it by usurping the functions of other people.

Students must be encouraged to use books. Instead of teaching them how to do it, in close cooperation with his teach- ing colleagues, there are librarians whe are so eager to be helpful that they do the work for the student. Instead of cultivating a mastery of the tools, that librarian is using the tool himself.

The librarian and the classroom teacher owe it to each other and primarily to their students, to understand and supplement rather than to contradict each other, and in the interests of genuine service to the student there are some detailed services which the librarian will not render.

The librarian who accepts his responsibility will at once see the need of work which involves vast mechanical detail. It is of great importance-but it is the part of your work which is the hardest for us laymen to understand and, therefore, the hardest for you to interpret.

\section{Simplification of Mechanics}

The simplification of the mechanics of library administration seems to me a laudable development so that librarians, as soon as may be, can be relieved from thr limitations of multitudinous technical details. Don't misunderstand me. The mechanics are vital. I suspect we have wasted personnel through the years, however, by not differentiating between clerical detail and library science. My suggestion is that librarians should become increasingly professional, scholarly, and executive, learning to delegate enough routine business to clerically-trained nonprofessional assistants so that the routine services essential to the library may not preclude the rendering of the service essential to the academic community.

Librarians on college campuses have traditionally been the Marthas of our academic life. It is time for you to assert your right to be Mary instead of Martha, though somebody is certainly needed to 
take care of the details. It should not be the main job of the librarian though the head of the library, like the head of any other department, must know they are being cared for adequately.

I have just asked the librarian to renderservice rather than perform services. That leads to the statement of a further problem for the librarian which he and his staff share with any other executive. What group defines the service which he should perform? To whom is he really responsible? Who actually controls the library? Nobody knows better than you how many people want to.

\section{Value of Library-Conscious Trustees}

Presidents tie your hands with always and inevitably inadequate appropriations. They are the spokesmen for the trustees who may or may not have more than a negatively financial interest in your work. I commend to you the important value of at least a few library-conscious trustees. If you don't have any, I strongly suggest that you begin to work upon your presidents to encourage the nomination and election of some board member who will be especially interested in library problems. You might suggest that if a trustee committee became acquainted with your problems, it might suggest ways to economize. That would sound promising to a gullible college president. If he knows anything, he will of course know that the more anyone knows of libraries the more sympathetic he becomes with the requests for more money. Be sure you keep the situation under control. Don't ask for trustee advice and then stand politely aside and let inexperienced financiers decide how you could economize. Stay by them when they investigate and educate them patiently, but get as many friends as possible at court.

Another way to make friends and influence trustees is to make friends with actual or potential donors. A far higher motive than the mercenary one implied herein is that of enlarging the circle of people who really care about the ultimate welfare of this, the frequently labeled "heart of the institution."

Another group, and one often more accessible than the trustees-who-votebudgets, is the faculty. In most institutions the faculty, of which the librarian should of course be a member, is charged with the responsibility of operating most of the institution. Because they are especially concerned with using your workroom and introducing students to the tools therein, your colleagues are eager to tell the librarian just how to run his organization. The only way I know for the librarian to control the situation is to tell them first. That's where the attitude of the service agency is of tremendous importance. If you are there to serve the educational influences of the campus, you will be willing to take the time to confer with the senior users of your resources.

Most faculty members, like most other people, are willing to let administrative officers, including librarians, do a good deal of work without much interruption, provided the reason for the program is clear and acceptable. To make it clear and acceptable takes a vast amount of everybody's time. Any administrator knows that he knows certain obvious ways of accomplishing important purposes, but he must learn sooner or later that it saves great emotional expenditure if he makes them obvious to his colleagues before adopting them.

Users of your books are the reason for your activity. It seems wholly reasonable 
that the faculty users should have excellent suggestions about making your service more serviceable.

\section{Faculty Committee an Asset}

Thus we are led to the conclusion so normal in academic organization, the committee. I hope you all have a standing committee of the faculty to assist you. Keep it standing, on its toes and ready to go with you. Don't let it sit upon you or your plans. There are some procedures which you will advocate which would commend themselves to your colleagues if they could all know as much as you do about library organization. You can't enlighten them all but, again, it is well to have friends at the court of faculty public opinion. A working committee of the faculty, giving you a chance to interpret your policies and dreams and, in time, making suggestions which have come to them from their colleagues-that can be a major asset in your efficient functioning.

Your students are also users of your tools. They approach you and your building from a different point of view from any of your other colleagues. Again you are fortunate if you can enlist the intelligent interest of a representative group which can assume responsibility for interpreting students to the library and the library to students.

I have implied, but have not stated it explicitly, that the librarian and his staff are one. That does not always follow, but it is one of the important arts of the executive to include his colleagues within the library so that each staff member can feel that he, too, shares in the destiny of the library.

- What I have been saying implies that the librarian is pre-eminently an administrative officer whose primary task is that of educating his associates sufficiently so that they will aid and abet his plans for library development. But nobody is only an executive, I hope. One of the chronic problems of all members of the library staff is that of deciding how to distribute one's personal efforts in the best interest of the institution. Shall you spend all your time in conference, at your desk holding interviews, circulating about the library keeping in touch with its actual functioning? Shall you try to be a scholar in your own right, demonstrating by your use of your tools how others might make use of them? Shall you write for popular or professional consumption?

\section{Growth and Development Important}

Nobody knows the answer, which must depend on you and the situation in which you find yourself. Suffice it to say this, however. Most people are useful in direct proportion to their own growth and development. There is a chronic controversy over the relative importance of teaching and research in college faculties. College administrators have been widely criticized for insisting on publications as a basis for promotion and tenure. It is absurd to ask for writing just for the sake of writing. It seems, however, reasonable to urge teachers of undergraduates to keep themselves exposed to the criticisms of their own contemporaries as well as of their students. In like manner, a librarian who can be something more than a faithful staff member is apt to be a more stimulating human being than he would otherwise be. The library, like all other parts of academic institutions, needs stimulating human beings.

Wellesley undergraduates have a song whose chorus goes like this, "Problems such as these have we, college is no snap 
you see. ..." It might well have been the text for this paper up to this point. In conclusion, I want to suggest that whatever the problematic nature of the librarian's life, the task he undertakes is worthy of all the ingenuity which he puts into it. This was so well formulated by the Wellesley College librarian, Blanche Prichard McCrum, in her annual report for I939-40, that I leave you with her message, hoping that I will thereby reveal the source of most of my ideas of what a college president should think about the college library.

\section{Protection against Shoddy Thinking}

The Crux of the Library Matter Today. Whatever the problems are that are presented by the practical and mechanical work of a library-and these are numerous because the library deals with small physical objects scattered on miles of shelves, with the facts of which these objects are the source, and with the unpredictable in the actions of human beings-patience and ingenuity can find for them either a solution or a workable compromise. But there is a much more serious implication in the present library situation than that of techniques. It is the need to do much more than has been done to make a discriminating reading so attractive that the habit becomes fixed as a protection against shoddy thinking. No one responsible for serving the book needs of students today can fail to feel a sense of terrible responsibility in the light of Adolf Hitler's reaction to the books of a few extremists. It is said over and over that the works of Nietzsche, the Ludendorffs, Alfred Rosenberg, H. S. Chamberlin, and a few others are the sources from which have been drawn the monstrous doctrines of Mein Kampf and the inspiration for the still more monstrous aftermath of those doctrines objectified in war. The course of history might have been different if this one man had had the mental habit of wide, critical, dispassionate reading, surely one of the greatest forces at work in the world for the maintenance of what America calls civilization.

In a college, the inculcation of this habit is primarily the obligation of the teaching faculty and it would serve no good purpose for the library-the auxiliary arm of the faculty - to set itself up to go beyond its function. But the fact remains that that function includes the provision of an intellectual home within library walls for a changing group of students, shown by actual count to number a third of the whole student body every day. To make such a provision a living, breathing, quickening part of college life for students is the supreme opportunity for college librarians, forever beyond their complete accomplishment, forever the object of their hopes.

\section{The American Culture Series}

ANNOUNCEMENT was made recently by 1 University Microfilms, Ann Arbor, Mich., that the work was finished on a microfilm collection of contemporary material which reflects American culture in the colonial period. The series includes approximately 250 texts and editions of representative writings about America and Americans. The main criterion in selection was cultural significance. Rare but basic works, never reprinted, were given preference. About seventy-five thousand pages were filmed for this series which is a companion to the American Periodicals Series and which can be ordered in the same manner and at the same price. This series makes available a selected group of Americana beginning with Christopher Columbus' Epistola, I493, and ending with Benjamin Rush's Essays, I 806. 